\title{
The Human and the Nonhuman,
} Beyond Anthropocentrism, Beyond Boundaries: A Material Ecocritical View on Monique Roffey's and Andrus Kivirähk's Work

\section{MARIS SÕRMUS}

\begin{abstract}
The article explores ecocritically nature-culture interactions in contemporary British and Estonian literature: Monique Roffey's and Andrus Kivirähk's writing. I start by elucidating the portrayal of nature, the way in which the writers under discussion reconsider anthropocentrism and established boundaries. Both novelists turn a delicate eye to nature, portraying a posthuman world where nature and culture are no longer dichotomous but perpetually entangled, challenging anthropocentrism and indicating a different, more envirocentric approach to literature. I will focus first on human-nonhuman interactions, analysing next how the normative human and nonhuman beings are transformed beyond recognition, shattering the anthropocentric core of the concept of agency and voice. In line with material ecocriticism, the currently emerging ecocritical branch that re-conceptualises nature as an active agent, the writers mingle the nonhuman with the human as a Subject, posing a threat to anthropo-normativity and envisioning an uncannily different reality. The article's final section explores the way how nature and culture are inextricably merged, not only their voices but also bodies, indicating the key new materialist idea of trans-corporeality - both culture and nature as tangled corporealities. In line with new materialism, the writers importantly revision the dominant dichotomous anthropocentric world, laying out a future that is naturalcultural.
\end{abstract}

Keywords: material ecocriticism, Monique Roffey, contemporary Estonian literature, natureculture, trans-corporeality, nature's voice and agency, anthropocentrism

Environment is one of the foremost present-day concerns in our environmentally fragile world, and this issue has also found its way into literary studies. Having gained prominence since the 1990s, ecocriticism as an environmental branch of literary criticism provokes thinking whether literature has done or should do anything to promote environmental awareness. Manifestations of the latter appear, for example, from such genres as apocalyptic narratives, 
science fiction and the recently emerging cli-fi (climate fiction). In particular, ecocriticism exhibits a unique position in the humanities, situated closely as it is to the science of ecology. Having "one foot in literature and the other on land" (Glotfelty 1996: xix), ecocriticism adds an ecological perspective to literary criticism and cultural studies. Characterised by its origin in the US and a strong Anglo-American focus, there is a growing recognition in ecocriticism of the importance of studying peripheral literatures. Though having rapidly expanded to Europe and Asia, literary ecology is a rather new direction in Estonia (bearing in mind this article's focus).

Expecting to provide a fresh look on national literature, I take as my ground of analysis Estonian and British-Caribbean literature: Andrus Kivirähk's Mees, kes teadis ussisonu (The Man Who Spoke Snakish, 2007) and Monique Roffey's The White Woman on the Green Bicycle (2009), exploring also finally Roffey's Sun Dog (2002), to illuminate the writers' similar boundary-crossing vision. Though on plot level the novels are significantly different, they all represent magic realism and are tied together by the protagonists' search for identity and place as well as the intense presence of the environment, both natural and built. Above all, interesting ecological ties emerge, illustrating some current debates in ecocriticism, such as nature's voice and agency. While Roffey's novels are acclaimed for their "terrific sense of place" (Roffey 2010: ii) and she tends to use nature as an anchoring point for her central concern of identity, the novel by Kivirähk has been acclaimed as the first Estonian econovel (Hasselblatt 2007: 1262), the tradition critical approach in the latter's case having concentrated largely on the aspect of the threatened position of the Estonian language and culture. Yet, the novels' green level has been largely overlooked by critics (except for Sõrmus et al 2013), ${ }^{1}$ and it is this gap the article intends to fill.

While Kivirähk is a highly popular writer in Estonia and the year 2007 has been termed respectively "the year of 'snake words" (Contra 2008: 119), Roffey is a new voice in West-Indian fiction, whose home, the Caribbean region, is vibrantly present in her novels. However, being a relatively unknown writer and classified usually in feminist terms, scholarly criticism on her is scarce, limited to book reviews in newspapers. Considering the above, my aim is to take the writers out of the usual national/feminist framework and discuss the currently unexplored ecocritical strand of their work, arguing that the writers radically revision current anthropocentric ideas, making nature speak and act. Intending thus to expand the narrow human-centred viewpoint

1 I have analysed some aspects of Kivirähk's novel earlier, looking at nature's role and representation. 
and foreground the environmental orientation in contemporary literature, the article examines (1) how nature-culture encounter is manifested in the novels and (2) how the writers subvert established ideas of humanism and move beyond anthropocentrism, considering its ensuing implications. To do so, I will introduce (material) ecocriticism and move to the portrayal of humannonhuman encounters, followed by the aspect of nature's voice and agency, leading us to the blurring of boundaries and bioregional ethic.

Literary ecology: re-visioning dualities and the material turn in ecocriticism

Ecocriticism is devoted to the study of nature-culture encounters, taking as its premise nature and culture, the nonhuman and the human. Concerned with the marginalised, this branch of literary criticism pays particular attention to the depiction of the more-than-human world. Such an earth-centred approach is distinguished against the more prevalent anthropocentric way of reading and seeing. Though the anthropocentric look is inevitably present, the ecocritical focus considers beings other than human; even more so, since nature is usually backgrounded in nature-culture dichotomy. As has been extensively theorised by Val Plumwood (1993), dualistic structures are exclusive, involving domination and inferiorisation, so that the inferior pole is incorporated into the selfhood and identity of the Master. In such a polarisation nature is, then, eclipsed and subjected to human needs. Particularly, the hierarchical view of nature/ culture extends back to the Great Chain of Being, scala naturae, in which the world is portrayed as a filigree of hierarchical forms from God to beasts. The position of mankind is within this order but above nature, and it is this separation that has been further criticised: the positioning of nature as a realm below culture rather than the one in which we are embedded (Ruether 1993).

Other dualisms, furthermore, also follow this mechanistic structure, such as man/woman, so that culture tends to be associated with men and nature with women. The latter focus on the parallel (treatment) of matter and mother has given rise to the critique of essentialism in ecofeminism; however, particularly interesting is the observation of women being a borderland, the initial mediator between natural and cultural (Soper 1995: 103). Above all, ecofeminist ethic sets out to reshape dualities in foregrounding interrelations and moving thus "from alienated, hierarchical dualism to life-sustaining mutuality" (Ruether 1993: 22). Such a reciprocal ethic is thus aimed both at a "just and sustainable planet" (ib. 21), requiring reconsideration of the human self as participating in the life cycle. The "understanding of nature and culture as interwoven rather than as a 
dualistic construct" has been generally recognised as one of ecocriticism's focal challenges (Wallace and Armbruster 2001: 4). The reciprocity has been also pertinently captured by the term "being-with" (Morton 2007: 17).

What is of importance in this relational "being-with" is the recognition of nature as an equally important subjectivity, alongside with culture. Moreover, current developments in ecocriticism have radically re-visioned the prevalent view of nature's passivity, arguing for nonhuman agency and voice. Namely, ecocritics growingly recognise nature as a speaking subject, capable of selfarticulation (Oppermann 1999), contrary to the dominant view of nature "as passive, as non-agent and non-subject, as the 'environment', or invisible background conditions against which the 'foreground' achievements of reason or culture [...] take place" (Plumwood 1993: 4). Based on the supposed lack of speech, nature tends to be viewed as an antithesis to the human, "without speech and incapable of it" (Soper 1995: 74). As Christopher Manes, one of the leading ecocritics to speak for nature's voice, has observed, nature is termed silent, because it is not a privileged voice (Manes 1996: 15). "No one really expects nature to answer" (ib. 22), for the speech and answers are thought to reside in texts and cultural utterances, not in the immediate phenomenal world.

We could thus generalise that the view of humans as speaking and thinking subjects has become so fossilised that nature is not supposed to speak. The concept of speech is inevitably anthropocentric, and even the fact that humans are a part of nature has only become an intellectual commonplace, not yet an emotional recognition (Sanders 1996: 194). I would argue that in order to feel nature as a subject, first an understanding of a subject behind the supposedly voiceless Other has to be reached, so as to engage in a more selfless interaction. With reference to loud environmental concerns and catastrophes, one could say that nature nevertheless speaks out, and should be thus recognised as a voice in its Otherness - however differently it is represented from that of our own.

Similarly to the reconsideration of the issue of voice, agency has become further foregrounded, giving rise to a particularly new direction in ecocriticism - material ecocriticism. The otherwise anthropocentric concept of agency, the capacity for change and acting, has been extended so as to refer also to the nonhuman material world. Matter is recognised as a vibrant force that possesses agency and is thus an "effective actor" (Iovino and Oppermann 2012a: 88) that "forms the fabric of events and causal chains" (Iovino and Oppermann 2012b: 451). This is perceivable, for instance, in a number of ecocatastrophes, which do effect change. In a similar vein, G. Huggan and H. Tiffin (2010: 191) have suggested redefining agency by the effecting of change itself, rather than "by the essentialist capacities apparently required to 
effect change". In re-conceiving the idea of agency, nature's subject position is clearly visible, as is also implicated by the nonhuman voice. This, in turn, forms a threat to anthropo-normative culture, indicating plurality of subjects and non-binary relations; or, resorting to Oppermann's pertinent statement, with its agency, "the nonhuman performs an uncanny act beyond human control, intermingling with the human along the way as a subject in itself" (Iovino and Oppermann 2012b: 461). The intermingling is further significant, highlighting nature as an equal subject, a body of its own in its intra-actions with culture. ${ }^{2}$

The mingling of subjectivities leads us to the overall result of the previous reconsiderations of agency and voice, captured by Stacy Alaimo's (2012: 476) key concept - "trans-corporeality" - "a new materialist and posthumanist sense of the human as substantially and perpetually interconnected with the flows of substances and the agencies of environments". Demonstrating that there are more actors and speakers to the world than the human species, the recent materialist ecocriticism is, indeed, vibrantly promising, provoking to inquire how such reconsiderations are manifested in literature and what their overall significance is.

\section{Encounters of the human and the more-than-human}

Before focusing on the reconsiderations, let us consider the nature-culture encounter as manifested in Mees, kes teadis ussisõnu and The White Woman on the Green Bicycle. Recounting the migration of George and Sabine Harwood from England to Trinidad, Roffey's novel highlights the nature-culture encounter as that of place and placelessness. George's encounter is characteristic of topophilia, for he is immediately attracted by the land, its smells and sounds: he "preferred these wild emerald hills, the brash forest, the riotous and unpredictable landscape of Trinidad to the prim hazy pastures of his own country, England" (Roffey 2010: 51). Loving nature, the sun, the ravishing land, where God came to design the planet earth in His image (ib. 269), it transpires that England, the former place becomes just a space, a mere dot on the world map. That is, contrary to Trinidad as a specific bounded place, England develops into an abstract space that he no longer cares about and which lacks the former meaningfulness to call it a place. ${ }^{3}$

2 See also Barad (2003) on "intra-actions" and "agential realism", matter's agency and voice.

3 On place/space discourse, beyond the article's scope, see, e.g., Lawrence Buell's The Future of Environmental Criticism: Environmental Crisis and Literary Imagination. 
Interestingly, George's encounter with Trinidad and its nonhuman beings is topophilic already before he has seen the place: he has murmured phrases, such as 'savannah grassland', 'golden lizards' and 'purple honeycreepers', in his sleep even (ib. 193). According to Sabine, George was already love-sick; his fantasies commenced before he reached the very island. This peculiar place-attachment is illustrative of the distant caring highlighted by a leading ecocritic, Lawrence Buell, who contends that one can care more about places one has never been to, places of imagination, than the ones known at first hand (Buell 2005: 73).

However, while George equates nature to paradise, Sabine feels completely placeless, stuck in the magically beautiful island, the people, beauties and beings of which she does not understand. Nothing makes sense: the weather is too warm, the nature too green, the people too black. Though she is physically in the place, mentally she does not belong and remains outside, a state describable in terms of "uncommitted insideness", to use Edward Relph's (1980: 143) term: being in a place one does not care about or belong to. Sabine has been deprived of her home, her past, her identity - and therefore she does not belong. In this vein, she develops a topophobic reaction to the nonhuman setting, or, even worse, a hate relationship, cursing "this goddamn island" (Roffey 2010: 48).

Contrary to George's "being-with" nature, Sabine clashes with the nonhuman, becoming symbolic of jealousy and her inability to belong. The significance of nature is thus not only on the level of representation but it pertains to the novel's very conflict, bringing forward a love triangle. The Trinidadian hills, in particular, are significantly portrayed as a green woman with a human-like body, so that George falls "head over heels with the sounds and smells, with the smiles and shapes, with all the bewitching qualities of another woman called Trinidad" (ib. 73). It is this nonhuman being that opens the chain of events and causes the disintegration of George and Sabine's marriage: George starts loving the nonhuman more than his own wife and the wife in turn withers in the beautiful surroundings, stuck in the place where she feels misplaced.

Turning to the interactions in Mees, kes teadis ussisonnu, the protagonist's Leemet's relation with nature is similar to George's identification with the nonhuman, describable as harmoniously "being with" the Other. This novel portrays forest-village relations in Estonia. The majority of forest dwellers move to the village and discard their former forest life. For Leemet, however, the forest is a meaningful place, where he chooses to stay, and he becomes even further rooted in the spot by learning the language of snakes and conversing with the nonhumans. ${ }^{4}$ The harmonious interrelation is manifested, as he develops a friendship with one of the snakes, Ints. Saving Ints' life, the snakes

\footnotetext{
4 This idiosyncratic aspect is discussed in next section.
} 
call Leemet their own son, not only a brother, who understands their language (Kivirähk 2010: 36). It is at the snake cave, where Leemet stays with the animals during many winters, that he feels having found again "a dry patch of land that the flood does not reach" (ib. 316). ${ }^{5}$ While the cave with its "pleasant darkness, soft, and caressing" (ib. 132) is a place of which Leemet has most beautiful memories, the village, as long as he has not been there, seems to be an unimportant space, with no special meaning for him.

Similarly, the human apes also represent a harmonious interaction with nature. Togetherness is perceivable already in the fact that they form a unit, talking together and moving side by side (ib. 59). They live in a cave, outside of which they feel not at home and which they rarely leave, so that the place functions as a concentric circle, a centre of attachment with which the apes feel an affinity. They delve even deeper into the inside by discarding the cave as too modern and regarding life at the top of a tree as the only solid ground: "they wanted to go as far back into the past as possible, for they believed that only the ancestors knew the truth and all the subsequent development was only an uninhibited falling into a swamp [...] secure ground was a branch of tree under the naked bottom" (ib. 154). Therefore, they are deeply attached to the nonhuman, and their home is moreover uniquely biocentric.

Differently from the apes and Leemet, for those who move to the village, the so-far regarded space becomes place, and they start to approach the previous inside - the forest - as the meaningless outside; for example, the forest is termed bush, contrary to the wide skies of the developed world (ib. 14). Because of the villagers' mental barrier of not wanting to admit their past and the vanishing of a common language, a dialogue of equals, and thus proper communication, is difficult to come by. Instead, there dominates a clash of oppositional Others. Leemet's comment on himself and the village master Johannes serves as a particularly cogent, symbolic illustration of this:

We lived in different worlds like two snails who don't manage to glance into each other's shells. Even if I told him that in my shell there are snake words and the Northern Frog, he wouldn't believe me, because he thought of seeing God and the Roman pope in his shell. (Ib. 170-171)

This metaphor of snails summarises vividly the encapsulation into the respective insides of the forest and the village, leading to the hierarchical view of nature as inferior and alien: snakes emerge in villagers' eyes as satanic beings, God's enemy (see, e.g., 162, 166). Moving to the village, the characters adopt

5 Hereafter, translations from Kivirähk's novel by the author of the article. M.S. 
SÕRMUS

Christianity and see nature as a realm below God, illustrating thus the hierarchical view of the Great Chain of Being. Drawing from Christianity - that all-powerful God creates nature, puts man in control of it and names it - the villagers' stance is understandable. They give explanations from their anthropocentric viewpoint, claiming respectively that God has made us and all the things of the world. However, in acquiring new attitudes, they become distanced from nature, contending that "snakes do not matter" (ib. 125) - what matters is foreign countries beyond the seas.

Even further, the villagers start denying the existence of the snake language, the language that they themselves once spoke. Nonhumans are, indeed, attributed with the ability to speak, highlighting the material ecocritical layer of the novel.

\section{Beyond anthropocentrism: reconsiderations of voice and agency}

Both writers attribute nature with voice and agency, making it speak and act out and indicating thereby divergence from anthropocentrism. But to proceed with the denial of nonhuman language in Mees, kes teadis ussisonnu, villagers claim that there are no snake words - it is only devil that makes Leemet hear things which do not exist (ib. 170). Even when he starts talking in the language, it is termed a meaningless hiss. According to Johannes, actually there are no such words:

How else could it be that the church knows nothing about them? [...] Even if there were snake words, the pope and the other holy men would understand them, but there are no such words, as God has not given snakes the ability to speak. They should not be spoken with but they have to be killed, that is, frightened off with prayer. (Ib. 169)

The anthropocentric monologue and insistence on nature's silence is in line with the rather prevalent view of nature as a silent beast, non-subject and nonagent, highlighted by Soper and Plumwood. Moreover, the belief in nature's muteness originates from the villagers' anthropocentric stance: nature having not been given a speaking status, so that it is relegated to the place of silence. Nonhumans are thus supposed to be silent due to anthropocentrism and the norm of human language.

Despite the denial, the snake language does exist. Namely, Kivirähk subverts the evil Biblical snake by making snakes speak out directly and participate in conversation with the last few forest dwellers, who, in turn, speak 
the animal language, snakish. Portraying snakes as the one-time brothers of humans and giving them a voice, it is further characteristic that humans themselves speak the nonhuman language. In so doing, there is a radical shift beyond anthropocentrism, blurring thereby the rigid nature-culture divide. An example of such a blurring is also Vootele's promise that Leemet will finally hiss so well that it becomes difficult to distinguish whether he is a human or a nonhuman (ib. 29).

Contrary to the humans speaking a nonhuman language in Kivirähk's novel, the hills in The White Woman on the Green Bicycle speak a human language. Sabine turns the issue also into a topic of conversation, noting to her son:

Oh, she talks back. Not always, but sometimes.

She?

The woman, up there. All around. Can't you see her? (Roffey 2010: 97)

The fact that it is the green mountain woman that is attributed with a voice is interesting, for the aspect of voice is a quality that has not always been associated with women - probably an attempt at upholding nature's and women's subject position. To adduce only one instance of voiced nature, Sabine turns to the hills, noting:

You're beautiful, you know that.

[The hills:] So are you.

I hate you. My husband loves you.

They all love me. (Ib. 262)

This voiced bodily nature becomes a competitor to Sabine, as George also turns to the hills, indicating the humans' problematic mutual communication, and, above all, nature's subject position. In short, both Roffey and Kivirähk radically revise nature's silence and blur human and nonhuman voices; and, what is particularly striking - nature and culture are able to speak each other's language. In other words, humans in Mees, kes teadis ussisõnu emerge partly as natural creatures, while Roffey turns nature into a cultural (speaking) creature.

In addition to the aspect of voice, the writers also challenge the anthropocentric core of the concept of agency, for the nonhumans are portrayed as 
SÕRMUS

actively acting out. As it has already transpired, nature is far from a passive entity in Roffey's novel but forms a looming presence and a speaking subject. Let us consider the following quote on nature's power and symbolic relevance:

Pink grapefruits so heavy they exploded on the branch, smashing heavily to the ground [...] [Avocados] bombed the grass for weeks [...] The lime trees spat yellow globes. The coconut palms were tall, lustrous, occasionally playing up, hurling a green nut at the dogs. The hibiscus hedge, a row of red trumpets heralding the sun. I wasn't leaving, I was retreating. Beaten by it all. (Ib. 430)

Here, nature emerges as an immediate presence, a vibrantly alive subject of its own, hurling its fruits - for the humans to pick. By doing so, Roffey subverts the traditional nature-culture power position - humans form a shadowed background to nonhuman power. This, in its turn, confirms the image of nature as an active agent, who has its effect, as it is Sabine who retreats.

There are further references to bombing, as in the instance of lashing rain (ib. 262), which makes birds stop their chatter and creates the impression as if it would like to bomb out the white people from Trinidad. Nature's agency manifests itself also at the seaside, where it seems as if the environment wants to take characters in its grip, pinning them down with a blanket of cloud (ib. 196). Acting out, the image of nature is far from meek and static; on the contrary, its vibrancy is well captured by Sabine's observation that "the mountain woman looked placid, but in fact the opposite was true. The mountain woman teemed with life" (ib. 331).

As for agency in Mees, kes teadis ussisõnu, the snakes do emerge as agentic subjects, biting people and causing death. The humans' supposed superiority is only a mask and a fateful one. For instance, the villagers cannot even catch animals for food, something which could be easily accomplished with the snake words. Not knowing or appreciating the nonhuman language becomes fateful in several instances: Magdaleena gets bitten by a snake, Leemet's father dies due to a bear, which gets confused by the man speaking German, and even Tambet, the defender of everything ancient, dies not knowing the ancient world's language.

Therefore, the anthropocentric hierarchy is broken and nonhumans and their language emerge as a powerful presence. Even though spoken by a minority, snakish does entail power: it is through the nature's language that Hiie manages to put the wolves she has to feed to sleep (Kivirähk 2010: 91). Also, Leemet's grandfather, thrown into the sea, survives thanks to seals, who hear the hiss (ib. 212). Similarly, Leemet, who fallen into a cellar and broken a few bones, survives thanks to the snake words, which penetrate through the 
ground to the snakes, unlike the boy's screams (ib. 140). Particularly, in the world where everyone else has forgotten the language Leemet understands the specific power - that already one correctly pronounced snake word can help kill another being or save a life.

Of further significance is the fact that the language functions as a basis for hierarchy inside nature. Contrary to the prevalent view of nature as harmonious, there are problematic relations also inside this world, as snakes are set apart from other animals by their language. Animals that cannot speak this language are termed inferior, ranging from stupid blockheads (hedgehogs) to mere rubbish (ants). At the bottom of this hierarchy of speaking are insects. Namely, mosquitoes, bees, and horseflies cannot speak snakish, because their brains are as little as a speck of dust (ib. 32). Thus, contrary to the superior snake language, "crab lice didn't understand the least the ancient language; they had only their nasty whine" (ib. 33). Bears, however, are considered to be "the wisest of animals, apart from snakes, of course, the brothers of humans" (ib. 16). Strikingly, then, although snakes are considered to be the wisest of animals because of speaking, they are still portrayed in conjunction to humans the supposedly wisest of all creatures. Humans still remain the very norm of intelligence, and the respective comparison captures well the inevitable anthropocentric bias against which all else is judged. However, more important than all the nonhumans speaking necessarily the same language is the fact that they are voiced and agentic.

Attributing nature with voice and agency, Kivirähk and Roffey indicate a divergence from the norm of anthropocentrism but go beyond that, blurring and challenging current distinctions as to nature and culture even more.

Beyond boundaries: the entanglement of nature and culture into natureculture

The studied writers alter the traditional view of nature and culture, reversing their power positions, and, most significantly, blurring the two. It is not only the nonhuman that is portrayed provocatively almost as human but vice versa: the human is also depicted in environmental terms. Let us turn hereby finally to Roffey's novel Sun Dog, which recounts the identity quest of the weather sensitive protagonist August, who is, indeed, a human with nonhuman features. His body starts to undergo transformations, parallel to changes in the seasons. In winter his body is covered with frost and icicles, dangling from his armpits and ears. With the arrival of spring, in turn, buds emerge and with rain, water 
seeps from his body. In summer his skin cracks and lilies start to blossom on his body, whereas in autumn, his hair, eyelashes, and fingernails fall off. These cyclical changes highlight nature-culture interrelatedness, and specifically, bioregional ethic, an approach critical of boundaries. Namely, the term bioregion refers usually to a "terrain of consciousness" (Buell 2005: 83), which instead of restrictive boundaries affords a view of the entities as one inclusive community. As a terrain of consciousness it is a specific view of the world which challenges a dichotomised vision of the entities.

Blurring the human and the nonhuman, Sun Dog becomes illustrative of bioregional ethic, and in doing so, it remains not the terrain of consciousness but the very real terrain of the human body. August is, in other words, one with nature and there is no border: "trapped in the ice was himself: his sweat, his own body fluid" (Roffey 2002: 91). Waking up one morning, August finds himself encased in ice; this bioregional inclusion, communicated here, suggests a blend of nature and culture, while the territory where the two come together is interestingly the body. Merging the human and the nonhuman, borders are melted so that at the encounter nature is no longer the Other but starts creeping in and becomes part of the human self, as the cyclical changes indicate. What is further suggestive of the bioregional sense of belonging is the fact that August regards the bud on his body with kinship, even love, feeling "an unspeakable alliance" (ib. 107) with nature. Twigs unexpectedly emerge from his ears, and August can do nothing but accept that his body is subject to external forces beyond his control. This fact, in turn, is in line with Oppermann's claim that the nonhuman possesses agency, intermingling with the human as a subject beyond human control.

To borrow Donna Haraway's term (1991: 151), the unique situation of intermingling could be encapsulated with the idea of a "naturalcultural" blend, in which a normative human being is transformed beyond recognition, being closer to an anthropomorphic creature rather than a usual human. As the human and the nonhuman are inextricably tangled in the character of August, it is no longer valid to talk about nature and culture, or rather, nature versus culture, but about an intermingled "natureculture". This intra-activism of culture with a powerfully agentic nature forms the core of material ecocriticism with its non-binary visions. As Oppermann has pertinently put it: "[...] in the age of environmental uncertainty, the natural and the cultural can no longer be thought of as dichotomous categories" (Iovino and Oppermann 2012b: 462). Instead, the juxtaposed entities have to be rethought as a circulating system (ib. 454), and this is the very vision that is laid out and enfleshed in Sun Dog.

This naturalcultural or bioregional blend is also central to Kivirähk's novel. Despite the number of clashes in this text, nature and culture are 
inevitably interlinked, and the entanglement, in particular, is manifested mostly via the character of Meeme. ${ }^{6} \mathrm{He}$ has no house but is often seen close to the ground, like a blade of a tree (Kivirähk 2010: 10). With his moss-covered clothes and a beard holding insects and plants, he is similar to "human turf" (ib. 153), which is especially indicative of the naturalcultural blend. Becoming more and more like turf, the grove keeper Ülgas once even mistakes Meeme for a moss angel or a forest mother, trying to bring him a sacrificial offering (ib.). Meeme, indeed, gradually merges with nature and even wishes to rot away in the place where he dies. Strikingly, he does finally dissolve into the earth:

He had lost even his last boundary markers, and [...] it was impossible to say where his body ended and where the moss began. [...] Meeme really looked like somehow dissolved in nature. It looked as if he were a melted and outstretched snow heap. The same moss that grew below and beside him also grew on the top of him. Besides, it seemed that he had not moved for a long time, because he was covered with a thick layer of autumnal leaves, fallen from the trees. His face was as dark as the soil and split here and there, and his eyes shone amidst this crust like dew drops. (Ib. 374)

Intermingling with nature, Meeme demonstrates pertinently the porous boundary between the human body and the nonhuman environment. In fact, the dissolution results in a unitary naturalcultural body, in which the distinctions between nature and culture are blurred. The unique result foregrounds the idea of trans-corporeality: the entanglement of humans and nature, whereas both of them have bodies of their own. In line with the material ecocritical view of "bodily nature" (Alaimo 2010: 2), Meeme forms a unitary body with nature, while August's body also undergoes environmental changes, and, the hills emerge, indeed, as a body.

Therefore, trans-corporeality with the underlying entangled bodies serves as a key concept to summarise the idiosyncrasy of voiced nature, perpetually entangled with culture. In such a portrayal, Kivirähk and Roffey indicate a radical move beyond boundaries, illustrating the emerging new materialist idea, conveyed by Iovino and Oppermann (2012b: 490): "There is no solid ground, no foundation, no safe place to stand [...] we dwell within and as part of a dynamic, intra-active [...] world".

6 However, consider also the apes who unite in their character the human and the animal and who retreat into a truly nonhuman home. The human and the nonhuman are mingled also by dwelling together in such nonhuman realms as the snake and the Northern frog's cave as well as the bear's den. 


\section{Conclusion}

I have attempted to foreground within an ecocritical framework the vibrant environmental orientation in contemporary literature. In so doing, I have explored nature-culture interaction, nature's voice and agency, as well as the comingling of culture with nature in Andrus Kivirähk's Mees, kes teadis ussisõnu and Monique Roffey's The White Woman on the Green Bicycle and Sun Dog. The nature-culture encounters are diametrically opposed, varying from unitary topophilic encounters to problematic conflicts and clashes due to non-identification or denial of the Other.

Furthermore, the current understanding of humanism is radically altered, extending the otherwise anthropocentric concepts of voice and agency to include passive nature. Nature emerges in these works as a wilful entity that is more than just a narrative space. In line with material ecocritical reconsiderations, proposed above all by Iovino and Oppermann, nature is made both to speak and act out, participating in human conservation. Though the villagers in Kivirähk's novel hierarchically insist on nature being the mute nonsubject, it remains their anthropocentric projection - the snakes are given a voice, and, moreover, some of the humans speak snakish. And similarly, Roffey makes the hills speak a human language. Human and nonhuman languages are blurred, so that humans appear to be natural creatures (speaking snakish) and nature herself is a voiced cultural creature in a position of power (the hills).

Thus, the distinctions as to nature and culture are blurred beyond recognition. Not only is the nonhuman likened to the human, but the human is also depicted in environmental terms: August's body undergoes environmental changes, while Meeme dissolves in nature. Instead of nature/culture, we are faced with their trans-corporeal entanglement - and inextricably so. Revisioning dominant understandings of nature, culture, voice, and agency, the writers provide a different less anthropocentric view of the world, challenging rigid boundaries and normativity. Doing so, the novels invite us to see beyond dichotomies, so as to recognise the reciprocity of our uncannily naturalcultural world. This challenging of anthropocentrism makes Kivirähk's and Roffey's writing valuable material for further ecocritical study, calling excitingly into question natural history (Kivirähk) and ecofeminist and postcolonial ecocritical critique (Roffey).

\footnotetext{
Maris Sõrmus

sormus@tlu.ee

Tallinna Ülikool

Narva mnt 25

10120 Tallinn

EESTI
} 
The Human and the Nonhuman, Beyond Anthropocentrism, Beyond Boundaries

\section{References}

Alaimo, S. 2010. Bodily Natures: Science, Environment, and the Material Self. Bloomington: Indiana University Press.

Alaimo, S. 2012. States of Suspension: Trans-corporeality at Sea. - ISLE (Interdisciplinary Studies in Literature and Environment), 19.3, 476-494.

Barad, K. 2003. Posthumanist Performativity: Toward an Understanding of How Matter Comes to Matter. - Signs: Journal of Women in Culture and Society, 28.3, 801-831.

Buell, L. 2005. The Future of Environmental Criticism: Environmental Crisis and Literary Imagination. Oxford: Blackwell Publishers.

Contra, 2008. Vikergallup: Eesti kirjandus 2007. - Vikerkaar, 3, 119-127.

Glotfelty, C. 1996. Introduction: Literary Studies in an Age of Environmental Crisis. C. Glotfelty, H. Fromm, eds., The Ecocriticism Reader: Landmarks in Literary Ecology. Athens: University of Georgia Press, xv-xxxvii.

Haraway, D. 1991. Simians, Cyborgs, and Women. The Reinvention of Nature. New York: Routledge.

Hasselblatt, C. 2007. Eesti esimene ökoromaan. - Looming, 8, 1262-1267.

Huggan, G. and H. Tiffin. 2010. Postcolonial Ecocriticism: Literature, Animals, Environment. London: Routledge.

Iovino, S. Oppermann, S. 2012a. Material Ecocriticism: Materiality, Agency, and Models of Narrativity.-Ecozon@, 3.1,75-91.

Iovino, S., Oppermann, S. 2012b. Theorizing Material Ecocriticism: A Diptych. ISLE, 19.3, 448-476.

Kivirähk, A. 2010. Mees, kes teadis ussisõnu. Tallinn: Eesti Keele Sihtasutus.

Manes, C. 1996. Nature and Silence. - C. Glotfelty, H. Fromm, eds., The Ecocriticism Reader: Landmarks in Literary Ecology. Athens: University of Georgia Press, 15-29.

Morton, T. 2007. Ecology without Nature: Rethinking Environmental Aesthetics. Cambridge: Harvard University Press.

Oppermann, S. 1999. Ecocriticism: Natural World in the Literary Viewfinder. - The Association for the Study of Literature and Environment, http:/www.asle.org/assets/ docs/oppermann.pdf (15.10.2013).

Plumwood, V. 1993. Feminism and the Mastery of Nature. London: Routledge.

Relph, E. 1980. Place and Placelessness. London: Pion.

Roffey, M. 2002. Sun Dog. London: Simon \& Schuster.

Roffey, M. 2010. The White Woman on the Green Bicycle. London: Simon \& Schuster.

Ruether, R. 1993. Ecofeminism: Symbolic and Social Connections of the Oppression of Women and the Domination of Nature. - C. J. Adams, ed., Ecofeminism and the Sacred. New York: Continuum, 13-29.

Sanders, S. R. 1996. Speaking a Word for Nature. - C. Glotfelty, H. Fromm, eds., The Ecocriticism Reader: Landmarks in Literary Ecology. Athens: University of Georgia Press, 182-195.

Soper, K. 1995. What Is Nature? Culture, Politics and the Non-human. Oxford: Blackwell. 
SÕRMUS

Sõrmus, M., Tofantšuk, J., Liiv, S. 2013. Ecocritical Considerations of Nature in Contemporary British and Estonian Literature. - Interlitteraria, 18.1, 108-123.

Wallace, K., Armbruster. K. 2001. Introduction: Why Go Beyond Nature Writing, and Where To? - K. Armbruster, K. Wallace, eds., Beyond Nature Writing: Expanding the Boundaries of Ecocriticism. Charlottesville: University Press of Virginia, 1-29. 